Revue belge de géographie

$4 \mid 2018$

Transformations of urban space after the fall of Socialism

\title{
The meaning of post-: Participatory urbanism in Lublin, Pilsen, and Yekaterinburg
}

La signification de post-: Urbanisme participatif à Lublin, Pilsen et Iekaterinbourg

Polina Golovátina-Mora, Ekaterina Zelenskaia, Varvara Golovatina, Piotr Celiński and Raúl Alberto Mora

\section{(2) OpenEdition}

\section{Journals}

Electronic version

URL: http://journals.openedition.org/belgeo/30464

DOI: $10.4000 /$ belgeo.30464

ISSN: 2294-9135

\section{Publisher:}

National Committee of Geography of Belgium, Société Royale Belge de Géographie

\section{Electronic reference}

Polina Golovátina-Mora, Ekaterina Zelenskaia, Varvara Golovatina, Piotr Celiński and Raúl Alberto Mora, « The meaning of post-: Participatory urbanism in Lublin, Pilsen, and Yekaterinburg », Belgeo [Online], 4 | 2018, Online since 04 January 2019, connection on 09 October 2020. URL : http:// journals.openedition.org/belgeo/30464; DOI : https://doi.org/10.4000/belgeo.30464

This text was automatically generated on 9 October 2020 .

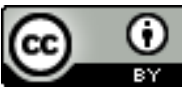

Belgeo est mis à disposition selon les termes de la licence Creative Commons Attribution 4.0 International. 


\title{
The meaning of post-: Participatory urbanism in Lublin, Pilsen, and Yekaterinburg
}

\author{
La signification de post-: Urbanisme participatif à Lublin, Pilsen et \\ Iekaterinbourg \\ Polina Golovátina-Mora, Ekaterina Zelenskaia, Varvara Golovatina, Piotr \\ Celiński and Raúl Alberto Mora
}

Socialism doesn't mean living behind a wall. Socialism means reaching out to others, and living with others. Not just to dream about a better world, but to make the world a better place (Good-bye, Lenin! Movie Script, n.d.).

\section{Introduction}

1 Despite a decades-long debate, "post-socialism" remains confined to "a spatialtemporal "container" (Hirt, Ferenčuhová \& Tuvikene, 2016, p. 500) that categorizes the development of the former "socialist" bloc territory after "socialism" merely as time and territory. Phaseal approach raises the ethical difficulty of seeking agreement on the border spatial-temporal. Any border implies generalisation, exclusion, silencing and marginalization of factors, actors, interests, sources of knowledge among other things and, so, limits our knowledge. Several "post-socialist" scholars agree on the artificiality of the concept (Ferenčuhová \& Gentile, 2016, pp. 483-488; Henig, 2010; Stanilov \& Sýkora, 2014). Bred during the Cold War (Hamilton, 2010, p. 60; Hirt, Ferenčuhová \& Tuvikene, 2016, p. 502, 506), "post-socialism" is still a politically overcharged term, that perpetuates resentment and us-them division.

"Transition" and "transformation", concepts at the core of the scholarly debates in the 1990s and early 2000s "fail to cover the multifaceted shape and the complexity of social and cultural change" (Dietzsch, 2010, p. 12). As teleological terms, they discredit the possibility of the alternative development of the society and territory and ways of knowing them (Henig, 2010, pp. 2-3; Hirt, Ferenčuhová \& Tuvikene, 2016; Humphrey, 
2002; Gans-Morse, 2004, pp. 321-322; Wiarda, 2001), stigmatise the region and its development as backward (Ferenčuhová \& Gentile, 2016, p. 490; Gans-Morse, 2004; Neumann, 1999; Reifová, 2017; Todorova, 2005), and discourage hope and belief in their potential. Coupled with the actual origins of the term in Northern/Western academic circles rather than in the actual "post-socialist" reality, "post-socialism" signals new colonialism, thus inspiring the conceptually and methodologically fertile comparison between "post-socialism" and post-colonialism (Chari \& Verdery, 2009; Chioni Moore, 2001; Hirt, Ferenčuhová \& Tuvikene, 2016; Hladík, 2013), Global South and Global East (Ferenčuhová \& Gentile, 2016, p. 485; Hirt, Ferenčuhová \& Tuvikene, 2016; Robinson, 2016; Yiftachel, 2006), and regions of the peripheral development.

3 As an ideologically and politically charged term, "post-socialism" can be inconsistent and contributes to the misinterpretation and even fear of socialism and communism, both in academia and everyday language: they existed and failed, proved to be wrong. Critical theories, starting with the Frankfurt School, however, characterise capitalist socio-economic and political structures as oppressive. "Victory" and the global influence of the capitalist system is seen not as universal human nature but rather as another form of totalitarianism and hegemony (Bohle, 2006; Saad-Filho \& Johnston, 2005; Traverso \& Lilaki, 2018). New materialism (St. Pierre, 2013; Braidotti, 2016) draws further attention to the oppressive nature of the ontology of the modern world-view based on the hierarchical Enlightenment philosophy that defines not only the social, economic and political development but also modern scholarship and standards of knowledge (Robinson, 2016).

4 When applied to urban studies, the term becomes equally problematic. Different scholars note, for example, that tendencies conventionally attributed to the "socialist" city are also present in other regions around the same time period (Robinson, 2016; Stanilov \& Sýkora, 2014; Hirt, Ferenčuhová \& Tuvikene, 2016). Contemporary "postsocialist" cities are characterized with the typical traits of global urban development, as opposed to a socio-political territory or a particular historical heritage. Also, focusing mainly on the "socialist" past, the term "post-socialist" reduces the significance of the "pre-socialist" trajectory of urban development (Hirt, Ferenčuhová and Tuvikene, 2016, p. 504). Considering the limitations of the term, critical urbanists have searched both for new approaches and its full reconsideration. Verdery, for instance, explored the connection with postcolonialism (Chari \& Verdery, 2009). Hirt, Ferenčuhová and Tuvikene (2016) proposed focusing on certain tendencies and categories in the analysis rather than base it on the territorial principle. Robinson (2016) suggested focusing on the multiplicities of the reality and knowledge about it and, in line with the nomad and processual thought of Deleuze and Guattari, united "individualising comparison" and "generative" comparative tactics (Trubina, 2018, p. 110).

5 The present article limits the usage of "post-socialism" to the territory for the selection of the examples - Yekaterinburg (Russia), Lublin (Poland) and Pilsen (Czech Republic), focusing on the global tendency of urban civic participation. The goal of the article is to explore the alternative meaning of post- from the perspective of post-media city (Guattari, 2000, 2013, 2015). As post-media is both normative and descriptive, the article discusses positive experiences of certain individual and group city renewal initiatives in search for potential lines towards more just cities. Interviews with urban activists and their testimonies provided the central data for the analysis. 


\section{Post-media city and participatory urbanism} architecture complexes" in the contemporary city, McQuire (2008, p. 15) speaks about the contemporary city as "media city". Considering the "contestatory" and "flattening" potential (Genosko, 2013; St. Pierre, 2013, p. 649) of the prefix "post-" in the nomad, processual and non-representational thought, we prefer the term post-media city. Guattari understands post-media not as a phase but as the transformative affordances for "active aesthetic appropriation" of the media space present in participative new technological media and their networks (Genosko, 2013, pp. 17-18). Post-media is not about media use for their own sake, but the methods and intentions of their use. For Guattari, rhizomatic and open-ended post-media is both resistance and an alternative to the "cynicism and the abdication of political and ethical responsibility" encouraged by neoliberalism and its mass media (Genosko, 2013, p. 17). It is affirmative, sustained by trust in the other, both human and non-human, as an agent of knowledge for its ever-coming possibilities for becoming in the world. It is relational, non-binary, nonhierarchical, and non-linear (Massumi, 2005; Braidotti, 2016). Guattari explains it through ecosophy, a world-view understood as the "concatenation of environmental, scientific, economic, urban and social and mental ecologies" (2013, p. 98). This positions post-media, as Guattari emphasizes, not as another divisive "totalizing or totalitarian ideology" but instead as "the prospect of an ethico-political choice of diversity" (2013, p. 98). Participative post-media affirm the agency of actors in the city through multiple media, conditions, and dimensions of thought, expression, knowing and living.

Guattari (2015) stresses the need to reconsider our vision of the city and its planning in an ecological or, to be more precise, ecosophical manner, as the survival of the human race, he insists, is contingent upon how we take the city into account for future human habitat and world organisation configurations. Ecosophy, as that unity of media, practices, and relations in their "agential separability" (Barad, 2003), leans far closer to the reality of the multiplicity of the world, helping the silenced and marginalised voices to recover their agency.

8 The post-media character of the contemporary city creates and stimulates imaginaries and actions that, rather than submit to technological traditions of communication (mass media in general), open themselves to broader new forms of actions and ways of directing social and cultural energy or capital. Understood as an ecosystem of all available media, tools and resources, post-media bares enormous critical and educational potential for discovering and cherishing one's autonomy and agency, offering a critical and conscious vision of one's own actions and needs and the ability to act accordingly. Post-media communication, knowledge, and space as an environment for such communication provide conditions for further empowerment and emancipation of a person, space and mind, colonized by the overwhelming political and economic market regimes or ideologies (Havel, 1978; Milosz, 1953).

9 Regardless of term choice, scholars characterize participatory urbanism as a "citizenled place-making activity" (Finn, 2014, p. 381), "bottom-up initiated, micro-spatial urban practices" (Fabian \& Samson, 2016, p. 166), and "temporary, participatory, flexible solutions that can adapt, evolve and change to meet a range of dynamic urban conditions" (Passmore, 2010). Here, participatory urbanism is defined as largely 
informal, at times unsanctioned and "extra-legal" (Douglas, 2016), "operating at the fringe of cultural production (and sometimes at the edge of the law)" (Passmore, 2010). These actions are "working with a range of urban public spaces... to generate a more effective, user-friendly built environment" (Passmore, 2010) and promote "reshaping and reinterpreting urban spaces [...] to capture and describe the contemporary growth in various forms of creative, localized attributions and alterations of urban environments" (Fabian \& Samson, 2016, p. 166). They also offer "innovative, sophisticated, and low-cost solutions to difficult or unaddressed urban problems" (Finn, 2014, p. 381) and promote "humane development" in the urban planning in accordance with human needs "linked strongly to dignity" (Laufen Manifesto, 2013). Their larger goal is to empower communities (Fabian \& Samson, 2016, p. 170), by "interven[ing] in the realm of professionalized urban planning and design, making what they see as functional, civic-minded improvements to the built environment" (Douglas, 2016, p.117).

Whether "socialist" or not, the goal of the city has always been to provide order, structure and security (Deleuze and Guattari, 2005; Fabian \& Samson, 2016; Finn, 2014; Tuan, 2013). Any anarchic manifestations, as Parra Valencia (2017, p. 96) writes, have always been rather peripheral. Unconventional forms of expression, ways of reading and organising the territory would be marginalised in order to "ensure values such as consensus, public safety, equity, efficiency, coordination of urban systems and others" (Finn, 2014, p. 382), without considering who benefits from such safety and consensus. The order here assumes the form of taming and controlling any other, which generally contradicts to another characteristic of the city - the actual encounter with the other (Simmel, 1950a, b). Playful commentary and temporary solutions of participatory urbanism (Finn, 2014, p. 381) do not invent but centre the other and their knowledge, meanings, sensibilities and "new empathies" (Mills, 2016), "promote new experiences" (Fabian \& Samson, 2016, p. 170) and "proffer an alternative social imaginary by living it" (Fabian \& Samson, 2016, p. 171). Its creativity comes from the margins. It reimagines the order and so contests it, creating "a critical challenge for urban governance, management and planning, acting as a kind of "vigilante urbanism"' (Finn, 2014, pp. 381-382) by decentralising, deterritorialising and disassembling the order.

Initiated as unofficial, participatory practices cooperate with the official structures, the striated - structure-oriented space (Deleuze and Guattari, 2005), whether it is the street, buildings, roads, monuments, or the city administration. They use them to open their meanings, transforming them into the smooth - nomad space even if temporary. In fact, its temporality accentuates its smoothness as it allows further reinterpretation by stimulating, shaking up the established structures and ways of thinking. They can be appropriated by the official institutions to make it long lasting but only if they are of a post-media city. Such practices, nomad by nature, go beyond any temporal-spatial territory. Social media facilitate relocating practices from one city to another (Blommaert \& Rampton, 2011), mobilising the public, and decentralising communication and authorship (Celiński, 2013; Mora, 2015; Mora, Pulgarín, Ramírez, \& Mejía-Vélez, 2018). Participatory forms of creative place appropriation "might mobilize or intensify the social qualities of public space", such as "to inscribe themselves in them; to attach themselves to them; and to get other people to relate and respond to them" (Fabian \& Samson, 2016, p. 170). 
12 The theory and philosophy behind the participatory urbanism and their studies is critical social theory. Their inspiration in Marx's social and political theory and his understanding of the nature of capitalism, make those studies, including the works by Deleuze \& Guattari (Holland, 2014; Sotiris, 2016; Thoburn, 2003), and participatory interventions conceptually close to socialism and communism as a social critical proposal.

13 Socialism and especially communism propose conditions for a person to discover and perfect their capacities together with social and spatial environment (Marx, 1999, Part 1). The correlation between labour, individual responsibility needs and self-realisation is central for them and inspire any forms of critical social writing. While such values may clash with the realities of the nation-state and political pressures and the essential human needs may be oppressed or silenced, they could still be understood at least at the intuitive level as, for example, they can be traced in the norms for human life in nearly all spiritual texts.

14 Citizen-led place-making activity was an ideal of the "socialist" world that was encouraged in the movies and literature in the Soviet Union, for instance. Examples of their implementation are also quite abundant. The egalitarian vision of the city focused on the development of public spaces, individual needs, or humane attitude appears as both idea and practice in the non- and post-"socialist" space. This all together reconfirms the artificiality of the classification of the societies and cities to the socialist, non- and post-socialist (Stryjakiewicz, MĘczyński, Stachowiak, 2014, p. 26), revealing the argumentative inconsistencies of such classification and its emerging categories (Robinson, 2016). Basic values of critical thought, responsibility and agency incorporated in the education at least in some parts of the "socialist" space (Golovátina-Mora, 2014, 2016; Oushakine, 2016) can facilitate understanding and appropriation of the values and foundations of the nomad thought.

\section{Feeling with the city - Yekaterinburg}

Yekaterinburg (2,5 million inhabitants), capital of the Sverdlovsk Oblast, is located in the central Ural region in Russia. Founded in 1723, it has predominantly been an industrial city throughout its history, which significantly defined its planning and architecture. In this section, we revise several participatory initiatives of the Centre of Applied Urbanism (Tsentr Prikladnoi Urbanistiki) in Yekaterinburg (https://vk.com/ cpuekb). We chose the Centre as an example because of their visibility and wellarticulated theoretical background. Besides, the Centre has been acting as a link between the communities, individual activists and city officials.

Based on Murunov's vision of the city as a person-oriented space (2015; 2016b, c; 2017), which continues the tradition of Russian urban theorist Glazychev, the Centre implements the idea of social design to overcome the alienation of people and spaces by developing citizens' agency. In this sense, the urban environment becomes an inclusive space (https://vk.com/cpuekb), where both local communities and individuals have specific limited tasks, needs and competencies. Therefore, the Centre's main tactic has been to develop interaction strategies among different actors, involving local residents, individual activists, officials, and businesses to solve specific urban problems. In order to maintain a dynamic, self-learning community, the Centre generally avoids assigning a single coordinator for the project. The Centre's "core" moderates the process of 
interaction and communication across different actors, but there is no official membership. Participants invest their time and finances in their own projects.

"Tsar Bridge" was the Centre's campaign to renew Dekabristy Street, an area around a neglected urban space and historical site that attracted the interest of private developers and constructors because of its central location. According to political analyst and urban activist Moskvin (2016), its mansions of the late $18^{\text {th }}-19^{\text {th }}$ century that survived the Soviet and post-Soviet urban transformations make the area a unique district with a significant aesthetic and historical cultural value for the city.

Along with the civic movements Real History and Green Evolution, Centre activists organized tours, exhibitions and cleaning sessions (subbotnik) and a historical and cultural festival in support of the area (https://vk.com/tsarskiimost) in Autumn 2017. This non-profit event was mostly funded by the activists themselves. The festival included art exhibitions, lectures and environmental seminars, workshops, concerts and interactive balls, a campaign for restoration of the merchant Nurov's garden, $19^{\text {th }}$ century, and the "Architectural Theatre" - an enactment of the $19^{\text {th }}$ century city life in the actual city environment. The chosen strategies aimed to raise awareness of how this area is still living, as well as helping the city, its citizens, local inhabitants, city administration, and other stakeholders see the past, present and potential cultural, recreational and aesthetic value of the area (Moskvin, 2016).

Up to 500 people took part in the festival. The activists noted that both citizens and mass media became increasingly interested in the ecology and history of the area. The festival had plenty of Internet media and radio coverage, triggering the creation of new networks among historians, ecologists, architects and artists.

Two other initiatives - the Day of the Iset' river and City Pond Committee provide further examples of these links across city stakeholders. Both crystallised the expressions of the public aspirations and grassroots initiatives to address and find solutions to the pressing urban planning and ecological problems. The City Pond Committee mobilised up to 2000 people to protect the city pond and the river from an unnecessary construction project. Chosen strategies included hug-the-pond events, seminars and public discussions, the open-source online publication of the construction projects to make them available for the broader public, publications of photos and personal stories, and memory exchanges connected to the pond. The pond was mostly presented as an important member of the city, active yet silenced. The events became a call to the citizens of different position and influence in the decisionmaking process for protection of the pond and an attempt to make the pond heard. The campaigns aimed at helping common citizens understand that their voices matter and that they are the city.

\section{Person $\leftrightarrow$ City approach to the city renewal - Lublin}

21 Lublin (342,000 inhabitants), capital of the Lublin Voivodeship in eastern Poland, is one of the poorest in terms of income per capita EU regions (Eurostat, 2015). This section will feature three examples of urban space renewal. We believe that these examples summarise the role of performativity and humanisation of the city, its memory, territory, and space. They also help us recognize the materiality of the city and the agency present in the streets, buildings and materials. 
The first example we will discuss is the city-wide effort to obtain the European Capital of Culture title in 2016. This European cultural policy program intended to "develop new forms of civic cohesion through inclusive and participative cultural events" (Jaffré, Raevskikh \& Pedler, 2017, p. 31). The process of preparation and participation in this competition took place between 2010 and 2012. Activists, scholars, and regional artists created the core team that was approved by the city administration. The discussion group, along with working groups, formed an extensive and efficiently working network that involved different stakeholders.

Although Lublin did not win the title, the application process became an incentive for empowerment (Skrzypek, 2016), indeed revealing the "hidden cultural potential of the cities" (Raevskikh \& Jaffré, 2016, p. 2). A Lublin street map forming a figure of a person, elaborated by Jan Bernat, Karol Grzywaczewski and Rafał Koziński (ESK, 2010, p. 138), visualising the motto "A person in the city - the city in the person" (Czlowiek w Miescie Miasto $w$ Czlowieku) - became the graphic expression of this agency and summarized the committee's feelings. Losing the city administration's active support once the formal goal of the process - the title - was not achieved was demotivating. The discovered potential or "taste" of agency, however, kept on inspiring the participants. They assessed the acquired knowledge positively and managed to use it in other city space renewal initiatives (Skrzypek, 2016). As one of the participants shared, working on the title application revealed not only what we can have but also what was already in Lublin.

24 The second example is the Civic Forum of Spatial Culture (Forum Kultury Przestrzeni) (http://ulublin.eu/; Skrzypek, 2017) in Lublin. This forum, a group of active citizens and professionals in various fields related to urban designing, planning and cultural management, provides another example of civic participation in the spatial and aesthetic development of the city. Participants of the Forum consult in official projects, actively comment on urban development in mass media, run their website, and organize workshops, meetings and seminars. The Forum's activities set the standards for the civic dialogue in the city, seeking further transparency in urban management (Lublin, 2017).

Our last example is Theatre NN, an interactive museum of the city Jewish heritage and a research centre. Theatre NN emphasises its theatrical performative and mobile nature, defying the static institutionalising status of otherwise traditional museums. The performance breaks the spatial-temporal borders and at every moment the tour can be taken outside, to the actual street. The streets, houses, and parts of the buildings become as living as the people who lived there. The Theatre employs all available media and resources in their work of making memory an everyday actor of the city (http://teatrnn.pl/about-us/; Pietrasiewicz, 2017). There is a dual relationship between the theatre and its visitors and workers. On the one hand, those individuals interacting in the theatre and the streets "interview" them in their daily interactions, learning more about the theatre and the streets. On the other hand, the theatre and the streets "interview" their dwellers, influencing them, making them feel the city, see, hear, touch and even imagine its aromas. 


\section{Guardian angels and the space for life - Pilsen} became the motto of the Angel Fest (Anděl Fest) charity festival (www.andeleplzen.cz). Everyone who lived in the city was able to propose a public space renewal project. The list of the projects was published on the Angel Fest official web site. The project was supported by The European Capital of Culture programme and a number of commercial and governmental organizations between 2014 and 2015. The Healthy Pathway is one of the Angel Fest projects: a 1,5-2 m long pathway was built by volunteers of such natural materials as small stones, pieces of wood and bark, cones and sand at the children playground in a popular urban public park. Two local mothers proposed the idea of the pathway. They believed that even in the city children and adults should be able to walk barefoot and feel different structures, learn about them, train their feet and senses, and be in the contact with nature. Together with volunteers, the authors of the idea worked on its maintenance. The project became a chance for two these women to express their creativity and concerns about the city environment and the desire to play an active role in its construction. The Path embodied these concerns and desires and still serves as a reminder of the diversity of the meanings and inhabitants in the city. It is also a good reminder that interested and concerned citizens can also propose bottom-up changes to the city space.

The program "Care for Space" (Pěstuj prostor) was part of the European Capital of Culture Pilsen event (http://pestujprostor.plzne.cz/). In the same vein as the other projects, it aimed at "establishing close relations between the wider population and specialists in developing the city environment with common projects, discussions and blogs" (O portalu). An interactive map of the finished projects and the new proposals 
was one of the strategies. Anyone was able to propose a project or join to any of the announced on the website projects to make the city a better place. The program selection committee would then choose one related to small improvements that could be done within 5-6 days by architects, engineers or volunteers. The "Care for Space" program works as a network builder and a mediator between the city administration and the civic initiatives. They also organize lectures, support festivals and city events to draw attention to the complex nature of the city.

These projects are the products of a rather small group of activists. They often remain unnoticed by other citizens or are taken for granted as centralized improvement by the city administration, as opposed to creative efforts by individual citizens to improve the city space. Albeit small, scattered, and often short-lived, they have helped transform the image of the entire city by changing individual places from unattractive or unnoticed to spaces that display either a vibrant public life or the existing conditions for such a change. They change the space around a person and their imaginaries of the city from an abstract, alien and foreign place to a brighter, proper and personalized space.

\section{Conclusions}

31 Looking at the examples from Yekaterinburg, Lublin, and Pilsen, we can see that social and emotional capital coupled with the recognition of one's needs and rights proved to be an important driving force of solidarity and civic movement. Although electronic communication and new technological media played an important role in establishing informal community networks, it was the mixture of technology and personal interaction what made the initiatives in this city successful. The described campaigns and projects are the examples of recognition of how post-media city and the more orthodox understandings of the city space, rather than being mutually exclusive, may work as symbiotic relationships. The amalgam of new media and community interactions enabled sharing knowledge and inspiration. They transformed the borders of the space by bringing the public to private spaces such as an apartment or an office and thus transcending the conventional frontiers of city, nation, or region.

The projects became a learning experience for the immediate participating parties. They allowed the city at large to recognize the individual and collective voices, making them audible, recognizing the oppression, and overcoming the alienation. This learning practical experience was a utopian practice that made visible the limitation of the existing order and the possibilities for overcoming them. Most importantly, it was a learning experience of how to dream (Levitas, 2013) individually and socially beyond the patterns of the mass culture (Murunov, 2016b). The experience proved the possibility of the change.

The post-media city is a city in motion and under construction of "the freedom to make and remake our cities and ourselves" (Harvey, 2008) in a non-prescribed and multidimensional way. The projects' tactic was "taking action by taking space" (Passmore, 2010). The activists mobilized all the spaces and means available - be it the streets, walls, rivers, abandoned corners, or memories, paintings, writings, or the Internet. They appealed to all the senses available in and for the transformation of the urban space. The multidimensionality and multimodality of their activity disassembled the accepted order, the traditional city space and its envisioning, the conventional 
communication, and the vertical order of decision-making process (Celiński, 2013; Mora, Golovátina-Mora, Orrego, Agudelo, Herrera, \& Quintero, 2018).

The discussed examples demonstrated both the simultaneity of thinking and living with and within the city space and the community-based nature of city renewal. The participants of the projects emphasized the transformational role of multidimensional and multilateral dialogue with and within the city. Just like graffiti, alternative theatres, underground radio and the press tried to reverse the logic of dominating mass media during real socialism, social networks, electronic forums, and correspondence transformed the social and political dynamics by changing the social imaginaries of communication while increasing its mobility and efficiency. New technological media facilitated horizontal networks and productive dialogue. The authorities learnt to talk to citizens recognising the efficiency of social media as a form of communication and the necessity of consulting meetings with the citizens, thus acknowledging their partnership status. Citizens, in turn, assumed shared responsibility for the city as a common good. They recognised the official practices of planning and managing and proposed adjusting them based on the community needs and the principle of efficiency. Cooperation between the city administration and the citizens is the example of self-generating mutual becoming between striated and smooth spaces.

The strategies and tactics used in the projects are recognisable. They are borrowed from other cities or inspired by them. Their goals are similar all around the globe. We argue that it is quite difficult and possibly counter-productive to pin it to "postsocialism". We must assume this as an invitation to transcend the debates about the social or political order and oppressive structures. Instead, we must focus on the humane, on the new empathies that could be and are already being generated in the societies all around the world, largely those are the socialist and communist values, values of individual and collective responsibility, value of the diversity of life and trust in the other and Self. In other words, focus on the values of the post-media city.

\section{BIBLIOGRAPHY}

Anděl Fest, official web, www.andeleplzen.cz.

BARAD K. (2003), "Posthumanist performativity: toward an understanding of how matter comes to matter", Gender and Science, 28, 3, pp. 801-831.

BOHLE D. (2006), “Neoliberal hegemony, transnational capital and the terms of the EU's eastward expansion", Capital \& Class, 88, pp. 57-86

BLOMMAERT J., RAMPTON B. (2011), “Language and superdiversity.” Diversities, 13, 2, pp. 1-21.

BRAIDOTTI R. (2016), “Posthuman critical theory”, in DEBASHISH B., PARANJAPE M.R. (eds.), Critical posthuman and planetary futures, New York, Springer, pp. 13-32. 
CELIŃSKI P. (2013), Postmedia. Cyfrowy kod i bazy danych

elektroniczny, Lublin, UMSC, http://www.postmedia.umcs.lublin.pl/.

CHARI C., VERDERY K. (2009), “Thinking between the Posts: postcolonialism, postsocialism, and ethnography after the Cold War", Comparative Studies in Society and History, 51, 1, pp. 6-34.

CHIONI MOORE D. (2001), "Is the post- in postcolonial the post- in post-Soviet? Toward a global postcolonial critique”, PMLA, 116, 1, Special Topic: Globalizing Literary Studies, pp. 111-128.

COOPER D. (2014), Everyday utopias: the conceptual life of promising spaces, Durham and London, Duke University Press.

DELEUZE G., GUATTARI F. (2005), A thousand plateaus: capitalism and schizophrenia, Minneapolis, University of Minnesota Press.

DIETZSCH I. (2010), "Perceptions of decline: crisis, shrinking and disappearance as narrative schemas to describe social and cultural change", Durham Anthropology Journal, 17, 1, pp. 11-35.

DOUGLAS G. (2016), “The formalities of informal improvement: technical and scholarly knowledge at work in do-it-yourself urban design", Journal of Urbanism: International Research on Placemaking and Urban Sustainability, 9, 2, pp. 117-134.

ESK Lublin 2016 Aplikacja (2010), Lublin, City Administration, Petit Skład, https://issuu.com/ krzywatwarz/docs/lublin_ap2016

EUROSTAT (2015), Regional GDP, http://ec.europa.eu/eurostat/news/themes-in-the-spotlight/ regional-gdp.

FABIAN L., SAMSON K. (2016), “Claiming participation - a comparative analysis of DIY urbanism in Denmark", Journal of Urbanism: International Research on Placemaking and Urban Sustainability, 9, 2, pp. 166-184.

FERENČUHOVÁ S., GENTILE M. (2016), "Introduction: post-socialist cities and urban theory”, Eurasian Geography and Economics, 57, 4-5, pp. 483-496.

Festival Tsarskii most, official web, https://vk.com/tsarskiimost.

FINN D. (2014), "DIY urbanism: implications for cities", Journal of Urbanism: International Research on Placemaking and Urban Sustainability, 7, 4, pp. 381-398.

Forum Kultury Przestrzeni, official web, http://ulublin.eu/.

GANS-MORSE J. (2004), "Searching for transitologists: contemporary theories of post-communist transitions and the myth of a dominant paradigm", Post-Soviet Affairs, 20, 4, pp. 320-349.

GENOSKO G. (2013), “The Promise of Post-Media”, in APPRICH C., BERRY SLATER J. \& ILES, A. et al. (eds.), Provocative alloys: a post-media anthology, Leuphana, Mute, pp. 14-25.

GLAZYCHEV V. (1995), Gorodskaia sreda. Tekhnologiia razvitiia, Moscow, Ladia.

GOLOVÁTINA-MORA P. (2014), “A forced road to a no-place: escapism as a form of inner emigration”, Studia Historica Gedanensia, 5, pp. 40-57.

GOLOVÁTINA-MORA P. (2016), "Remembering the future or in search for the 'Marvellous far", in OWCZARSKI W., ZIEMANN Z. \& CHALUPA A. (eds.), Memory: forgetting and creating, Gdańsk, Sopot, Gdansk University Press, pp. 210-223.

Good-bye, Lenin!, Movie Script, https://www.springfieldspringfield.co.uk/movie_script.php? movie=good-bye-lenin. 
GUATTARI F. (2000), The three ecologies, London and New Brunswick, New Jersey, The Athlone Press.

GUATTARI F. (2013), “Towards a post-media era”, in APPRICH C., BERRY SLATER J., ILES A. et al. (eds.), Provocative alloys: a post-media anthology, Leuphana, Mute, pp. 26-28.

GUATTARI F. (2015), Machinic eros. Writings on Japan, Minneapolis, University of Minnesota Press.

HARVEY D. (2008), “The right to the city”, New Left Review, 53, https://newleftreview.org/II/53/ david-harvey-the-right-to-the-city.

HAVEL V. (1978), Moc bezmocných, http://vaclavhavel.cz/showtrans.php? cat=eseje\&val=2_eseje.html\&typ=html.

HENIG D. (2010), “Intimacies from the margins of Europe”, Durham Anthropology Journal, 17, 1, pp. 1-10.

HIRT S., FERENČUHOVÁ S. \& TUVIKENE T. (2016), “Conceptual forum: the "post-socialist" city”, Eurasian Geography and Economics, 57, 4-5, pp. 497-520.

HLADÍK R. (2013), “A theory's travelogue: post-colonial theory in post-socialist space”, PostColonial Europe, http://www.postcolonial-europe.eu/en/essays/153-a-theorys-travelogue-p.

HOLLAND E. (2014), "Deleuze and Guattari and minor marxism”, in HABJAN J. \& WHYTE J. (eds.), (Mis)readings of Marx in continental philosophy, London, Palgrave, pp. 99-110.

HAMILTON G. (2010), "Rediscovering our shared qualities in ever-changing situations: why postsocialist anthropologists should (and do) study rhetoric”, Durham Anthropology Journal, 17, 1, pp. 35-64.

HUMPHREY C. (2002), “Does the category 'postsocialist' still make sense?”, in HANN C. (ed.), Postsocialism: ideals, ideologies and practices in Eurasia, London, Routledge, pp. 12-15.

JAFFRÉ M., RAEVSKIKH E. \& PEDLER E. (2017), “Immigration, identity and mobility in Europe: inclusive cultural policies and exclusion effects", IAFOR Journal of Cultural Studies, 2, 2, pp. 31-51.

Klub strážných andělů, official web, http://www.plzen2015.cz/cs/andele.

Laufen manifesto for a humane design culture (2013), München, https://www.ar.tum.de/fileadmin/ w00bfl/www/02_Aktuell/01_Meldungen/2013/Laufen_Manifesto.pdf.

LEVITAS R. (2013), Utopia as method: the imaginary reconstitution of society, New York, Palgrave, Macmillan.

LUBLIN CITY ADMINISTRATION (2017), Budzet obywatelski, https://lublin.eu/mieszkancy/ partycypacja/budzet-obywatelski/aktualnosci/.

MARX K. (1999), “Critique of the Gotha programme”, in Marxists archive, https:// www.marxists.org/archive/marx/works/1875/gotha/index.htm.

MASSUMI B. (2005), “Translator's Foreword: Pleasures of Philosophy”, in DELEUZE G., GUATTARI F. (eds.), A thousand plateaus: capitalism and schizophrenia, Minneapolis, MN, University of Minnesota Press, pp. ix-xv.

MCQUIRE S. (2008), The media city. Media, architecture and the urban space, Nottingham, Sage.

Městská plovárna Plzeň, official web, www.plovarna.plzne.cz.

MILLS K. (2016), Literacy theories for the digital age, Bristol, Multilingual Matters.

MIŁOSZ C. (1953), The captive mind, London, Martin Secker and Warburg. 
MORA R. A. (2015), “City literacies in second languages: New questions for policy and advocacy”, Journal of Adolescent \& Adult Literacy, 59, 1, pp. 21-24.

MORA R. A., GOLOVÁTINA-MORA P., ORREGO T. S., AGUDELO E., HERRERA A. M. \& QUINTERO H. (2018), Qualitative inquiry as a multiverse: What would this mean for research design?, Paper presented at the Fourteenth International Congress of Qualitative Inquiry, University of Illinois at UrbanaChampaign, USA.

MORA R.A., PULGARÍN C., RAMÍREZ N. \& MEJÍA-VÉLEZ M. C. (2018), "English literacies in Medellin: The city as literacy”, in NICHOLS S., DOBSON S. (eds.), Learning Cities: Multimodal explorations and placed pedagogies, Singapore, Springer, pp. 37-60.

MOSKVIN D. (2016), "Raion Tsarskogo mosta - kulturnyi ostrov Ekatetrinburga”, Medium, 1.11.2016, https://medium.com/@dmitry_moskvin/\%D1\%80\%D0\%B0\%D0\%B9\%D0\%BE\%D0\%BD\%D1\%86\%D0\%B0\%D1\%80\%D1\%81\%D0\%BA\%D0\%BE\%D0\%B3\%D0\%BE\%D0\%BC\%D0\%BE\%D1\%81\%D1\%82\%D0\%B0\%D0\%BA\%D1\%83\%D0\%BB\%D1\%8C\%D1\%82\%D1\%83\%D1\%80\%D0\%BD\%D1\%8B\%D0\%B9\%D0\%BE\%D1\%81\%D1\%82\%D1\%80\%D0\%BE\%D0\%B2\%D0\%B5\%D0\%BA\%D0\%B0\%D1\%82\%D0\%B5\%D1\%80\%D0\%B8\%D0\%BD\%D0\%B1\%D1\%83\%D1\%80\%D0\%B3\%D0\%B0-474ec80fb723.

MURUNOV S. (2015), Gorodskie soobshestva - pravo na gorod, Lecture in Gorkii Park, Moscow, Shaninka, https://www.youtube.com/watch?v=aay7qjlu2Ug.

MURUNOV S. (2016a), Triokhsloinaia model goroda, Lecture at the $6^{\text {th }}$ School of the Center of the Applied Urbanism, Ekaterinburg, 16-19.04.2016, Teleport, https://www.youtube.com/watch? v=jDsgtMGcW04.

MURUNOV S. (2016b), Tvorkcheskaia ekonomika, Lecture at School of the Center of Applied Urbanism, Samara, 25-28.06.2016, Zobr TV, https://www.youtube.com/watch?v=jDsgtMGcW04.

MURUNOV S. (2016c), Perezagruzka postsovetskogo goroda, Lecture at School of the enter of Applied Urbanism, Samara, 25-28.06.2016, Zobr TV, https://www.youtube.com/watch?v=UiH2dcuWLdk.

MURUNOV S. (2017), Neformalnye soobshestva - vozmozhnost' razvitia goroda, Lecture, https:// www.youtube.com/watch?v=dXwINDpc5uM.

NEUMANN I. (1999), Uses of the Other. "The East" in European identity formation", Manchester, Manchester University Press.

OUSHAKINE S. (2016), “Translating communism for children: fables and posters of the revolution", Boundary 2, 43, 3, pp. 159-219.

PARRA VALENCIA J. (2017), "La ciudad epimeteica. Amnesias y anestesias urbanas", in ACOSTA RÍOS B., ROJAS LÓPEZ M. \& PARRA VALENCIA J. (eds.), Mitópolis, Medellín, Instituto Tecnológico Metropolitano, Universidad Nacional de Colombia, pp. 57-118.

PASSMORE M. (2010), “Participatory urbanism”, Urbanist, 489, http://www.spur.org/publications/ urbanist-article/2010-02-01/participatory-urbanism

Pěstuj prostor, Pilsen, official web, http://pestujprostor.plzne.cz/

PIETRASIEWICZ T. (2017), Theatre of memory by the NN Theatre, Lublin, Petit SK Lublin.

RAEVSKIKH E. \& JAFFRÉ M. (2016), “Mirovoi opyt: Programma "Evropeiskaia stolitsa kultury”, Interview, Strelka Institute for Media, Architecture and Design - Moscow, https://hal.archivesouvertes.fr/hal-01655407/file/Interview_Moscow_Strelka_Institute_Journal\%20\%20\%E2\%80\%8B\%D0\%9C\%D0\%B8\%D1\%80\%D0\%BE\%D0\%B2\%D0\%BE\%D0\%B9\%20\%D0\%BE\%D0\%BF\%D1\%8B\%D1\%82\%3A\%20\%D0\%9F\%D1\% 
REIFOVÁ I. (2017), “The pleasure of continuity: re-reading post-socialist nostalgia”, International Journal of Cultural Studies, pp. 1-16, https://doi.org/10.1177/1367877917741693.

ROBINSON J. (2016), "Starting from anywhere, making connections: globalizing urban theory", Eurasian Geography and Economics, 57, 4-5, pp. 643-657.

SAAD-FILHO A., JOHNSTON D. (eds.) (2005), Neoliberalism: a critical reader, London, Pluto press.

SIMMEL G. (1950a), “The metropolis and mental life”, in WOLLF K. (ed.), The Sociology of Georg Simmel, Glencoe, Ill., The Free Press, pp. 409-426.

SIMMEL G. (1950b), “The Stranger”, in WOLLF K. (ed.), The Sociology of Georg Simmel, Glencoe, Ill., The Free Press, pp. 402-408.

SKRZYPEK M. (2016), “Sieciowanie społeczne Lublin - ESK”, in Kultura - Polityka - Rozwój. o kulturze jako , "dźwigni” rozwoju społecznego polskich metropolii i regionów, Wolność i solidarność, 44, Gdańsk, pp. 190-201, https://www.kongresobywatelski.pl/wp-content/uploads/2017/05/wis-44.pdf.

SKRZYPEK M. (2017), “Przyjazne miasto. Dekada Forum Kultury Przestrzeni”, Kultura Enter, 8, 77, http://kulturaenter.pl/article/przyjazne-miasto-dekada-forum-kultury-przestrzeni/.

SOTIRIS P. (2016), “The many encounters of Deleuze and marxism”, Deleuze Studies, 10, 3, pp. 301-320.

ST. PIERRE E. (2013), “The posts continue: becoming”, International Journal of Qualitative Studies in Education, 26, 6, pp. 646-657.

STANILOV K., SÝKORA L. (2014), "Postsocialist suburbanization patterns and dynamics: a comparative perspective", in STANILOV K., SÝKORA L. (eds.), Confronting suburbanization: urban decentralization in postsocialist Central and Eastern Europe, Ch. 9, Oxford, Wiley.

STRYJAKIEWICZ T., MĘCZYŃSKI M. \& STACHOWIAK K. (2014), "Role of creative industries in the post-socialist urban transformation", Quaestiones Geographicae, 33, 2, pp. 19-35.

Teatr NN, official web, http://teatrnn.pl/about-us/.

THOBURN N. (2003), Deleuze, Marx and politics, New York, Routledge.

TODOROVA M. (2005), "The trap of backwardness: modernity, temporality, and the study of Eastern European nationalism”, Slavic Review, 64, 1, pp. 140-164.

TRAVERSO E., LILAKI D. (2018), "Enzo Traverso: Neoliberalism is the totalitarianism of our times", interview, Marginalia, https://marginalia.gr/arthro/enzo-traverso-neoliberalismtotalitarianism-times/.

TRUBINA E. (2018), “Comparing at what scale? the challenge for comparative urbanism in Central Asia”, in HORN P., D'ALENCON A., DUARTE CARDOSO P., CLAUDIA A. (eds.), Emerging urban spaces, Cham, Springer International, Ch. 6.

Tsentr Prikladnoi Urbanistiki, official web, https://vk.com/cpuekb

TUAN Y.-F. (2013), Romantic geography: in search of the sublime landscape, Madison, Wisconsin, University of Wisconsin Press.

WIARDA H. (2001), "Southern Europe, Eastern Europe, and comparative politics: transitology and the need for new theory", East European Politics and Societies, 15, 3, pp. 485-501.

YIFTACHEL O. (2006), “Re-engaging planning theory? towards 'South-Eastern' perspectives", Planning Theory, 5, pp. 211-222. 


\section{ABSTRACTS}

This article analyses civic participation in three "post-socialist" cities - Yekaterinburg, Russia; Lublin, Poland; and Pilsen, Czech Republic. The conceptual mix of nomad thought and Guattari's concept of post-media city provides a fresh perspective to study today's trends in contemporary cities. It helps rethink the possibilities for urban and global social development, more just and inclusive societies, and the assessment and disruption of past and newly acquired hierarchical systems. Using interviews and testimonies of urban activists, participants of the projects aimed to recover urban public spaces and reclaim "the right to the city". The deliberate choices and examples from these three cities show similar demand for the recognition of individual voices and needs of the citizens and their inclusion in urban planning processes where horizontal organization and self-governance foster radical and longer-lasting change through temporary performative actions.

Cet article analyse la participation civique dans trois villes " post-socialistes » - Iekaterinbourg, Russie; Lublin, Pologne; et Pilsen, République tchèque. Le mélange conceptuel de la pensée nomade et du concept de ville post-média de Guattari offre une perspective nouvelle pour étudier les tendances actuelles dans les villes contemporaines. Cela permet de repenser les possibilités de développement social urbain et mondial, de sociétés plus justes et inclusives, ainsi que l'évaluation et la perturbation des systèmes hiérarchiques passés et nouvellement acquis. À l'aide d'interviews et de témoignages d'activistes urbains, les participants aux projets visaient à récupérer des espaces publics urbains et à revendiquer "le droit à la ville ». Les choix délibérés et les exemples de ces trois villes montrent une demande similaire pour la reconnaissance des voix individuelles et des besoins des citoyens et leur inclusion dans les processus de planification urbaine où l'organisation horizontale et l'autogouvernance favorisent un changement radical et durable par des actions temporaires performatives.

\section{INDEX}

Keywords: nomad thought, post-media city, public space renewal, social activism, urban planning, Yekaterinburg, Lublin, Pilsen

Mots-clés: pensée nomade, ville post-média, rénovation de l'espace public, activisme social, urbanisme, Iékaterinbourg, Lublin, Pilsen

\section{AUTHORS}

\section{POLINA GOLOVÁTINA-MORA}

Universidad Pontificia Bolivariana, polina.golovatina@upb.edu.co

\section{EKATERINA ZELENSKAIA}

Independent Scholar, renardile@yandex.ru

\section{VARVARA GOLOVATINA}

University of West Bohemia, golotvav@ujp.zcu.cz

\section{PIOTR CELIŃSKI}

Marie Curie Skłodowska University, piotr.celinski@poczta.umcs.lublin.pl 


\section{RAÚL ALBERTO MORA}

Literacies in Second Languages Project, Universidad Pontificia Bolivariana, raul.mora@upb.edu.co 